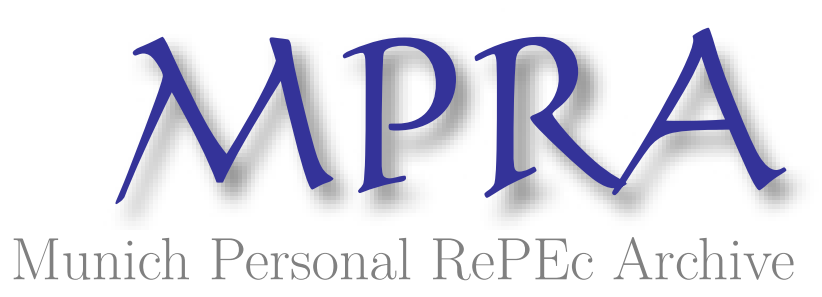

\title{
Stock Price Response to Earnings Announcements: Evidence from the Nigerian Stock Market
}

\author{
Afego, Pyemo \\ University of Dundee
}

15 March 2011

Online at https://mpra.ub.uni-muenchen.de/33931/

MPRA Paper No. 33931, posted 07 Oct 2011 16:56 UTC 


\title{
Stock Price Response to Earnings Announcements: Evidence from the Nigerian Stock Market
}

\author{
Pyemo Afego ${ }^{1}$ \\ Graduate Student at the School of Accounting and Finance \\ University of Dundee, DD1 4HN, United Kingdom
}

\begin{abstract}
This paper examines the stock market reaction to annual earnings information releases using data on the Nigerian Stock Exchange. Using the event study method, the speed of reaction of the market to annual earnings information releases for a sample of 16 firms listed on the exchange is tested. Significant abnormal price reactions around earnings announcements suggest the earnings announcements contain value-relevant information. We find that the magnitude of the cumulative abnormal returns is dominated by significant reactions 20 days before the earnings release date which suggests that a portion of the market reaction may be due to private acquisition and, possibly, abuse of information by insiders. The persistent downward drift of the cumulative abnormal returns, 20 days after the announcement, is inconsistent with the efficient markets hypothesis, and therefore suggests that the Nigerian stock market does not efficiently adjust to earnings information for the sample firms within the study period.
\end{abstract}

JEL classification: G14; G10; G12

Keywords: earnings announcements; abnormal returns; event studies; Nigeria; emerging markets

\footnotetext{
${ }^{1}$ Contact email address: pyemo.afego@yahoo.com. The author would like to thank Professor John Okpara of the College of Business, Bloomsburg University of Pennsylvania, and two anonymous referees for their helpful comments on the earlier version of the paper.
} 


\section{Introduction}

One of the central themes in finance literature has been the concept of stock market efficiency and how information is reflected in stock prices. According to the semi-strong form of the efficient markets hypothesis $(\mathrm{EMH})$, stock prices reflect all publicly available information, and trading on the basis of this information should not be profitable (Fama, 1970).

Beginning with the seminal work by Beaver (1968) and Ball and Brown (1968), the empirical literature on stock market reaction to information disclosure is vast and covers a wide range of information disclosures such as dividend announcements, stock splits, macroeconomic policy changes and merger announcements. One area that has received considerable attention is the influence of earnings information disclosure on stock prices. Many of the studies conducted in this area have focused on the US and, to a lesser extent, the UK. The evidence reported in these studies is largely consistent with the information content hypothesis and the EMH, which is that earnings announcements do contain value-relevant information and that stock markets react quickly and efficiently to this information.

Interestingly, there are a number of reasons why the evidence documented for developed markets may not apply to Africa's emerging markets. According to Alford et al., (1993), the varying accounting standards and information environments across markets are likely to impact differently on the manner in which stock markets in different regions and countries react to information. Additionally, developed markets are highly sophisticated, highly liquid, closely regulated and considerable amount of resources is devoted to securities research and analyses. Emerging markets, on the contrary, are characterized by a relatively large number of poorlyinformed and unsophisticated investors, low liquidity levels, weak legal, regulatory and institutional framework, and operational bottlenecks (Osei, 2002). 
Given the scanty research on emerging capital markets in Africa, and their potential to provide significant portfolio diversification benefits (Harvey, 1994), the need for further research on the efficiency and responsiveness of markets in the region to information disclosures has become deeply imperative. This study therefore, serves to fill this gap by assessing the informational efficiency of the Nigerian stock market with respect to firms' earnings information releases. A study of share price adjustment to earnings announcements is of significance to investors, policy makers, regulators and researchers. Investors and portfolio managers, keen on increasing their portfolio returns, would be interested in identifying opportunities for profitmaking by trading around earnings disclosure dates in emerging markets. For policy makers and regulators in developing markets, stock market inefficiency is a matter of concern because it implies less-than-optimal allocation of investment resources within the economy. Lastly, evidence from analysing stock price reaction to earnings announcements in a developing market may throw more light on whether the theory of efficient markets is supported, or contradicted, by empirical findings, and this is of significant interest to researchers.

Most previous studies on informational efficiency of the Nigerian stock market relied on the use of monthly and weekly price data and were conducted in the period prior to the introduction of major reforms on the NSE. The current study marks a departure from previous studies and contributes to the literature in a number of important ways: First using daily prices, we investigate whether significant abnormal returns can be generated in the Nigerian stock market in the period surrounding firms' annual earnings disclosures. Second we assess the information content of earnings disclosures using recent data (2005 to 2008) which enables us to capture recent trends in globalisation, technological progress and reforms in financial market regulation. Third, we measure the speed of reaction of the market to earnings information 
disclosures of the sample firms. Finally, by highlighting the implications of our findings for behavioural finance theory, our study provides an interesting insight on the influence of investor sentiment on the price-discovery process of securities traded on Nigeria's stock market.

Using event study methodology, our results suggest that all the cumulative abnormal returns (CARs) before the announcement day are significantly different from zero (0) and negative. This result suggests that annual earnings announcements on the Nigerian stock market have useful information content which investors use in repricing the value of securities. However, given the peculiar nature of the information environment in Nigeria, the results may also be interpreted to be suggestive of a high incidence of private acquisition of information in the pre-disclosure period. We also find that the significant negative trend of the CARs persists up to 20 days after the announcement. This suggests that while the market may anticipate and impound news beforehand, it fails to fully incorporate all relevant information into stock prices, quickly and correctly. While the evidence contradicts the semi-strong form of the EMH, it appears to offer some support for behavioural theory.

The rest of the paper is organised as follows. The next section briefly reviews the extant literature on the information content of financial disclosures and its implications for the efficient markets hypothesis and behavioural finance theory. In section three (3) we provide an overview of the stock market development in Nigeria. The data and methodology are discussed in section four (4) while our results and findings are reported in section five (5). The implications of the findings of the study are discussed in section six (6). Finally, section seven (7) offers some concluding observations and recommendations. 


\section{Brief Review of Relevant Literature}

Early research document evidence of the association between security returns and the release of announcements of company earnings, dividends, issues of new shares and stock splits (e.g. Ball and Brown, 1968; Beaver, 1968; Fama et al, 1969). The major weakness of these early studies was their inability to isolate the effects of earnings changes from other information releases, due in part, to the use of monthly and weekly data.

Subsequent studies have attempted to control for contemporaneous factors by using high frequency data such as intra-day and daily data ${ }^{2}$. While a few of these more robust studies have examined the information content of macroeconomic news releases (e.g. Ederington and Lee, 1995; Green and Watts, 1996; Fleming and Remolona, 1999 and Fifield et al 2002), others have examined the price reactions to the information content of earnings disclosures (e.g. Firth, 1981; Pope and Inyangete, 1992 and El Sharkawy and Garrod, 1996). In a general context, the conclusions from these studies, most of which focused on the US and UK, is that capital markets are efficient i.e. all information that is known and knowable by investors is incorporated quickly and unbiasedly in the price of a security, leaving no room for profitable trades.

However, the validity of the efficient markets hypothesis (EMH) has been questioned as several recent studies have reported evidence that significant abnormal returns can be generated by trading on the basis of public information. For example, Kausar and Taffler (2006) found that stocks of UK firms in distress that have a publicised going concern audit report tended to experience significant negative price reactions ranging between $-24 \%$ and $-31 \%$. Other studies which question the EMH have found evidence of slow post-announcement stock price adjustment to earnings disclosures. Sponholtz (2005), using the event study method, examined

\footnotetext{
${ }^{2}$ See Kothari and Warner (2006) for a review of event studies which measure the information content of financial and economic information disclosures
} 
the information content of annual earnings announcements in the Danish stock market. Utilizing data from 1999 to 2001, Sponholtz found significant abnormal price reactions in the period surrounding the announcements. Contrary to the EMH, the abnormal price reactions persist several days after the announcement, suggesting that the Danish stock market may not be informationally efficient. Sponholtz (2005) attributes the slow post-announcement adjustment of prices to the small size of the Danish stock market.

Similarly, Cready and Gurun (2010) examined aggregate market reaction to earnings announcements and found evidence of market return persistence beyond the post earnings announcement period. Their finding is consistent with the 'post earnings announcement drift' (PEAD) phenomenon, which relates to the tendency for stock prices to continually drift after information disclosures, leaving room for profitable trading opportunities. This interpretation is consistent with findings from other recent studies (e.g. Chordia and Shivakumar, 2005; Ng et al, 2008 and Chordia et al, 2009) which suggest that the profitable trading opportunities created by the PEAD are inconsistent with the EMH.

On the whole, the documented anomalies in the finance literature have contributed to the emergence of behavioural finance theorists who challenge the EMH by postulating that financial markets might fail to reflect economic fundamentals under a number of conditions which can result in significant and persistent biases (Subrahmanyam, 2007). Hirshleifer (2001) explained that investors are not always rational and may not correctly process all available information while forming their expectations of an asset's future performance and, as such, trades could occur as a result of such irrationality. Several other reasons have been advanced for the seeming irrational behaviour of investors and markets. For example, Gutierrez and Kelley (2006) and Avramov et al., (2006) suggest the phenomenon may be caused by illiquidity and high trading 
costs, and this is of huge relevance particularly to emerging stock markets in Africa as these markets are characterized by dismally low liquidity levels, high transaction costs, weak regulations, thin-trading and poor communication infrastructure (Osei, 2002; Aloui, 2005 and Chordia et al., 2005).

In the case of developing African markets, relatively few studies on informational efficiency have been conducted (e.g. Olowe, 1998; Oludoyi 1999; Osei, 2002; Adelegan 2003, 2009). Studies examining the informational efficiency of the Nigerian stock market, in particular, failed to find evidence of efficiency, and thus conclude that the Nigerian stock market is not informationally efficient (e.g. Olowe, 1998; Oludoyi, 1999 and Adelegan, 2009). Using monthly data, Olowe (1998) examined the response of stock prices to stock splits. He examined 86 stock splits for 59 companies between 1981 and 1992 and found that abnormal returns could be earned. Olowe however failed to isolate the price-impact of other simultaneous events occurring near the dates of announcements of stock splits and this may have influenced the overall results.

Similarly, Oludoyi (1999) examined the reaction of stock prices in Nigeria to earnings announcements. Using weekly data, Oludoyi (1999) concludes that the evidence suggests that the Nigerian stock market is not semi strong form efficient as stock prices drift 10 weeks after the corporate earnings results had been released to the public. In a recent study, Adelegan (2009) examined the speed of adjustment of stock prices to dividend announcements for a total of 742 announcements dates. Adelegan, using the event study method, reports evidence of significant positive abnormal returns for dividend paying firms, 30 days from the date of the announcement. Similarly, the abnormal returns for dividend omitting firms were significantly negative over the same period. Adelegan concludes that the Nigerian stock market is not semi-strong form 
efficient, and that dividend announcements do contain relevant information to which stock prices react.

What emerges from a review of the literature for the Nigerian case is that most of the studies relied on monthly and weekly data, and were conducted prior to the year (1999) when the NSE adopted the use of automated trading system. Technological development, recent reforms in financial market regulation and increased integration and internationalization of the Nigerian capital market may have increased the availability of financial information and this has important implications for the efficiency of the stock market.

This paper makes an important contribution to the literature by using daily prices and recent data in order to capture current trends in the behaviour of stock prices around earnings announcements dates. In addition, we mark a departure from previous studies for Nigeria by highlighting the implications of our findings for behavioural finance theory. Such a study may provide an interesting insight on the influence of investor sentiments in the price-discovery and decision-making process of investors in an emerging market which is important in Africa.

\section{Brief Overview of the Stock Market Development in Nigeria}

The Nigerian capital market was established in 1960 as the Lagos stock exchange. The exchange was renamed Nigeria Stock Exchange (NSE) in December 1977. Trading commenced at the exchange in 1961 with about nineteen (19) securities. By the end of 1971, there were 34 securities quoted on the NSE. The exchange witnessed some modest growth between the years 1972 to 1980 when the indigenisation policy ${ }^{3}$ was introduced. Since 1981, there have been significant changes to the NSE in terms of structure and operations.

\footnotetext{
${ }^{3}$ The indigenisation policy mandated all multinational companies operating in the country to get listed on the Nigerian stock exchange and sell major stakes of their equities to Nigerian nationals.
} 
These changes have resulted in a significant growth in the number of listed firms and trading activity. The major stock market index - the Nigerian All Share Index - was introduced in 1984. In 1985, the second-tier securities market (also known as the unlisted securities market) was introduced. In 1999, the NSE adopted the use of Automated Trading System. In 2009, the NSE received a big boost towards its drive at internationalization when Bloomberg announced that real-time stock market data from Nigeria can be accessed from its database by the global investment community. As at 2009, market capitalization stood at N7.03 trillion while the number of listed securities was 266 .

\section{Data and Methodology}

Daily closing prices and annual earnings announcement dates were obtained for a sample of firms listed on the NSE between 2005 and 2008 (inclusive). The sample selection was based primarily on the criteria that only firms with the required financial and market information during the period 2005 to 2008 were included in the study. Thus stocks with insufficient data points, either as a result of non-trading or lack of financial and market information, were excluded from the sample. Also, since most companies in Nigeria announce their earnings and dividends simultaneously, we had to select only companies which had earnings and dividend changes in the same direction in order to control for the effect of dividend announcements. Thus, the above criteria resulted in a final sample of 44 earnings announcements for a total of 16 firms $^{4}$ over the 4 year period 2005 to 2008 .

\footnotetext{
${ }^{4}$ The sample firms represent approximately $70 \%$ of the total equity market value.
} 
The methodology employed in this study is the standard event study methodology. We use daily data and set the event window at twenty (20) days before and twenty (20) days after the earnings announcement day. The announcement day is represented by day zero (0).

$$
-20,-19,-18,-17,-16, \ldots-2,-1,0,+1,+2, \ldots+16,+17,+18,+19,+20
$$

Due to the peculiar nature of the information environment in developing stock markets, it is possible that the market reaction starts long before the actual announcements ${ }^{5}$. The choice of a wide event window (of $-20,+20$ ) is made in order to capture this possible pre-event reaction. We further set the estimation window at 100 days before each annual earnings announcement.

To estimate abnormal returns, we employ the market model since it is more widely used in empirical research and its assumptions are statistically and empirically reasonable (MacKinlay, 1997).

The market model is specified thus:

$$
R_{i t}=\alpha_{i}+\beta_{i} R_{m t}+\varepsilon_{i t}
$$

Where $R_{i t}=$ returns on stock i at time period t

$$
\begin{aligned}
& \mathrm{R}_{m t}=\text { market return at time } \mathrm{t} \\
& \varepsilon_{i t}=\text { error term }
\end{aligned}
$$

In order to test for market reaction to the announcements, we estimate abnormal returns (AR) at the time of the announcement, and before and after the announcement. The abnormal return is obtained thus:

$$
A R_{i t}=R_{i t}-\alpha-\beta_{i} \mathrm{R}_{m t}
$$

${ }^{5}$ Osei (2002) points out that the nature of the information environment in emerging stock markets in Africa, characterized by weak legal, regulatory and institutional structures, leaves room for potentially significant predisclosure information leakage. 
The $A R$ is the percentage change in share price below or above what would normally be expected to occur. To improve the informativeness of the analysis of abnormal returns, we average the ARs across the observations for all events, $\mathrm{N}$, using the model:

$$
\overline{\mathrm{AR} t}=1 / \mathrm{N} \sum \text { ARit }
$$

The ARs are tested for statistical significance using the t-statistic:

$$
\overline{t \mathrm{AR}}=\mathrm{AR} t / \mathrm{SD}(\mathrm{AR} t)
$$

Where $\mathrm{SD}(\mathrm{AR} t)=$ standard deviation of $\mathrm{AR} t$ calculated over the estimation window.

The null hypothesis to be calculated is that the mean abnormal return in the period surrounding the event day is zero. A mathematical explanation of the hypothesis is provided below:

$$
\begin{aligned}
& H_{0}: A R=0 \\
& H_{1}: A R \neq 0 \\
& \text { Where; } A R=\text { Abnormal Returns }
\end{aligned}
$$

From the above, we predict that new information contained in earnings announcements will not be quickly reflected in security prices, thus leaving room for statistically significant abnormal returns to be generated on the basis of trading on the information contained in earnings disclosures. Considering the fact that our study period, 2005 to 2008, coincides with the period 
when the Nigerian stock market index recorded massive growth, we expect ARs to be significantly different from zero, but also largely positive.

In order to make generalisations and to draw an overall inference for the market reactions to earnings announcements, we analyse the cumulative abnormal returns (CARs) for the 41-day event window, from the start of the event period $t_{-20}$ (day -20$)$ up to time $t_{+20}($ day +20$)$ as follows:

$$
\mathrm{CAR} t=\Sigma 1 / \mathrm{N} \Sigma \mathrm{AR} t
$$

The CARs for each stock is obtained by summing abnormal returns (ARs) over the event window. Again we aggregate the CARs to obtain the cumulative mean abnormal returns and then test for statistical significance using a similar t-statistic to the one we adopt for testing the statistical significance of abnormal returns. The new t-statistic is calculated thus:

$t \mathrm{CAR}=\mathrm{CAR} t / \mathrm{SD}(\mathrm{CAR} t)$

Where $\mathrm{SD}(\mathrm{CAR} t)=$ standard deviation of CAR $t$ calculated over the event window.

\section{Results and Findings}

This section presents the results of the study. First, however, we present descriptive statistics for each of the stock returns in our sample. The mean (Mean), standard deviation (StDev), minimum (Min), maximum (Max) and skewness (Skew) were calculated for each of the 16 stocks over the 4-year period and are reported in Table 1.

The returns for all the 16 stocks showed significant negative skewness, an indication that the return distributions of the stocks in our sample have a higher probability of being negative. 
Table 1: Descriptive and Statistical Information for Sample Companies

\begin{tabular}{|c|c|c|c|c|c|c|c|}
\hline Stock & Mean & StDev & Min & Max & Skew & Sector & NEA \\
\hline ACCESS & -0.00580 & 0.11106 & -2.04413 & 0.08762 & -17.24 & Banking & 3 \\
\hline FBN & -0.00050 & 0.04973 & -0.70699 & 0.26762 & -7.96 & Banking & 3 \\
\hline PZ & -0.00119 & 0.03490 & -0.24559 & 0.06719 & -1.31 & Conglomerates & 2 \\
\hline ECOBK & 0.00068 & 0.05550 & -0.70148 & 0.04879 & -8.50 & Banking & 2 \\
\hline ZENITH & -0.00260 & 0.05791 & -0.81342 & 0.08475 & -10.54 & Banking & 3 \\
\hline WAPCO & -0.00281 & 0.11798 & -1.33809 & 1.22543 & -3.97 & Building & 3 \\
\hline GTB & -0.00219 & 0.07784 & -1.12395 & 0.46551 & -8.74 & Banking & 3 \\
\hline UBN & -0.00210 & 0.04529 & -0.51232 & 0.05196 & -6.37 & Banking & 2 \\
\hline OANDO & -0.00141 & 0.07021 & -1.09790 & 0.33221 & -10.55 & Petroleum & 3 \\
\hline NESTLE & -0.00070 & 0.03297 & -0.25156 & 0.16714 & -1.57 & Food \& Beverages & 3 \\
\hline NB & -0.00091 & 0.03021 & -0.31466 & 0.06294 & -3.01 & Breweries & 3 \\
\hline GSKL & -0.00265 & 0.06313 & -0.77319 & 0.49412 & -4.88 & Healthcare & 3 \\
\hline MOBIL & -0.00041 & 0.03303 & -0.23820 & 0.11441 & -0.98 & Petroleum & 3 \\
\hline DIAMOND & -0.00345 & 0.05228 & -0.81394 & 0.09718 & -10.33 & Banking & 3 \\
\hline FIDELITY & -0.00358 & 0.09416 & -1.41655 & 0.98167 & -6.22 & Banking & 3 \\
\hline OCEANIC & -0.00181 & 0.10341 & -1.54881 & 0.04879 & -14.06 & Banking & 3 \\
\hline
\end{tabular}

Note: 'Mean' is the average return for each stock over the sample period; 'StDev' is the standard deviation of returns while 'Min' and 'Max' are the minimum and maximum stock returns respectively; 'Skew' is the skewness for each of the stock distributions; 'NEA' refers to the number of earnings announcement event for each firm in the study; 'Sector' refers to the sector classification for each firm as classified on the Nigerian Stock Exchange

The behaviour of abnormal returns (ARs) and cumulative abnormal returns (CARs) for our sample firms are presented in Table 2. In theory, a stock market is informationally efficient with respect to earnings disclosures if no one can earn ARs by trading on the basis of the information contained in firms' earnings news. First, this means that the market will quickly and correctly anticipate earnings changes before they are made. Second, since the earnings 
information is fully impounded into prices, no ARs should exist around the earnings disclosure day (day 0).

Table 2: Mean ARs and CARs around earnings announcements*

\begin{tabular}{|c|c|c|c|c|}
\hline Day & AR (\%) & ${ }_{t} \mathrm{AR}$ & p-value & CAR (\%) \\
\hline-10 & -0.36 & -0.66 & 0.509 & -6.6030 \\
\hline-9 & -0.62 & -1.14 & 0.253 & -7.2258 \\
\hline-8 & -1.00 & -1.83 & 0.067 & -8.2233 \\
\hline-7 & -0.35 & -0.65 & 0.519 & -8.5751 \\
\hline-6 & -0.10 & -0.19 & 0.851 & -8.6776 \\
\hline-5 & -0.56 & -1.03 & 0.304 & -9.2373 \\
\hline-4 & 0.71 & 1.30 & 0.096 & -8.5267 \\
\hline-3 & -0.28 & -0.51 & 0.612 & -8.8030 \\
\hline-2 & -0.60 & -1.11 & 0.268 & -9.4063 \\
\hline-1 & -0.24 & -0.44 & 0.663 & -9.6437 \\
\hline 0 & -0.57 & -1.04 & 0.296 & -10.2128 \\
\hline 1 & -0.28 & -0.51 & 0.609 & -10.4914 \\
\hline 2 & 0.29 & 0.54 & 0.295 & -10.1985 \\
\hline 3 & -0.40 & -0.74 & 0.462 & -10.5997 \\
\hline 4 & -0.05 & -0.09 & 0.928 & -10.6486 \\
\hline 5 & -0.50 & -0.92 & 0.360 & -11.1478 \\
\hline 6 & -0.56 & -1.04 & 0.300 & -11.7120 \\
\hline 7 & 0.83 & 1.53 & 0.063 & -10.8799 \\
\hline 8 & 0.04 & 0.08 & 0.467 & -10.8352 \\
\hline 9 & -0.76 & -1.39 & 0.166 & -11.5908 \\
\hline 10 & 0.17 & 0.32 & 0.375 & -11.4178 \\
\hline
\end{tabular}

Notes: $\mathrm{AR}=$ abnormal returns; $t \mathrm{AR}=\mathrm{t}$-statistic of abnormal returns; $\mathrm{CAR}=$ cumulative abnormal returns

* The length of the announcement period has been shortened from 20 days to 10 days before and after the announcement day, purely for presentation purposes 
Visual inspection of Table 2 indicates that the mean ARs and CARs are significantly different from zero and negative. Based on the evidence from the sample of firms in our study therefore, we reject the null hypothesis, $\mathrm{H}_{\mathrm{o}}$, that mean abnormal returns in the period surrounding the event day is zero $(0)$.

A careful observation of the results presented in table 2 reveal that the ARs and CARs tend to stay significantly negative 10 days before the announcement date. The CAR on day -10 is significantly negative at $-6.6030 \%$. The CAR continues to drift in the same direction up to day 0 , with negative (cumulative) excess returns of $-10.213 \%$. The negative mean CAR increases from $-10.213 \%$ to $-11.418 \%$ as the announcement period varies from the particular announcement day to 10 days after the announcement. The significant and negative CARs in the period surrounding announcement disclosures suggests that earnings announcement do convey information which the market uses in revising share prices. However the persistent drift of the mean CAR, 10 days after the announcement day, indicates that the market failed to adjust instantaneously and unbiasedly to earnings disclosures, further suggesting that significant negative ARs could be earned by trading on the information contained in the annual earnings information disclosure for the sample firms in our study.

The results we obtain is consistent with results obtained in earlier studies on Nigeria and Ghana by Oludoyi (1999) and Osei (2002) respectively, which found that prices drifted beyond the earnings announcement week. On the whole, while our results are inconsistent with the efficient markets hypothesis (EMH) which states that the price reaction to new information must be instantaneous and unbiased, we find support for the information content hypothesis that earnings information disclosures do contain relevant information which drive stock prices. 
To further aid the analysis, the results of the CARs for various holding periods are presented in table 3 .

Table 3: Behaviour of mean CARs for holding period relative to announcement day

\begin{tabular}{cccc}
\hline $\begin{array}{c}\text { Holding period } \\
\text { (relative to announcement day) }\end{array}$ & CAR (\%) & CAR & p-value \\
\hline From Day -20 to -1 & & & \\
From Day -10 to -1 & -9.64 & -3.87 & 0.000 \\
From Day -1 to +1 & -3.40 & -1.93 & 0.053 \\
From Day +1 to +10 & -1.09 & -1.13 & 0.258 \\
From Day +1 to +20 & -1.21 & -0.68 & 0.494 \\
& -3.45 & -1.39 & 0.166 \\
\hline
\end{tabular}

Notes: $\mathrm{CAR}=$ cumulative abnormal returns; $t \mathrm{CAR}=\mathrm{t}$-statistic of the cumulative abnormal returns

The results from table 3 indicate that the mean CARs for the 20-day and 10-day holding periods prior to the announcement date are negative and statistically significant at $-9.64 \%$ and $-3.40 \%$, with a $t$-statistic of -3.87 and -1.93 respectively. The CAR for the 3 -day event window (i.e. the day before and after the event day) is also negative and significant at $-1.09 \%$ with a $t$ statistic of -1.13. The CARs for the 10-day and 20-day post announcement holding period are also significantly negative at $-1.21 \%$ and $-3.45 \%$ respectively. The results clearly indicate that the greatest magnitude of price reaction takes place in the pre-announcement period, day -20 to day -1 , where the reported mean CAR is significantly negative at $-9.64 \%$.

The results thus suggest that while the Nigerian stock market reacts to news contained in earnings information disclosures, stock prices adjust long before the announcement occurs. This finding further gives the impression that, in general, the actual dates for annual earnings disclosure in Nigeria are, for the most part, 'uneventful'.

The negative abnormal returns associated with earnings announcements can be more clearly observed by plotting the CARs on days surrounding earnings announcements. This result is presented in Fig. 1. 
Figure 1: Graphical Plot of CARs around earnings announcement days

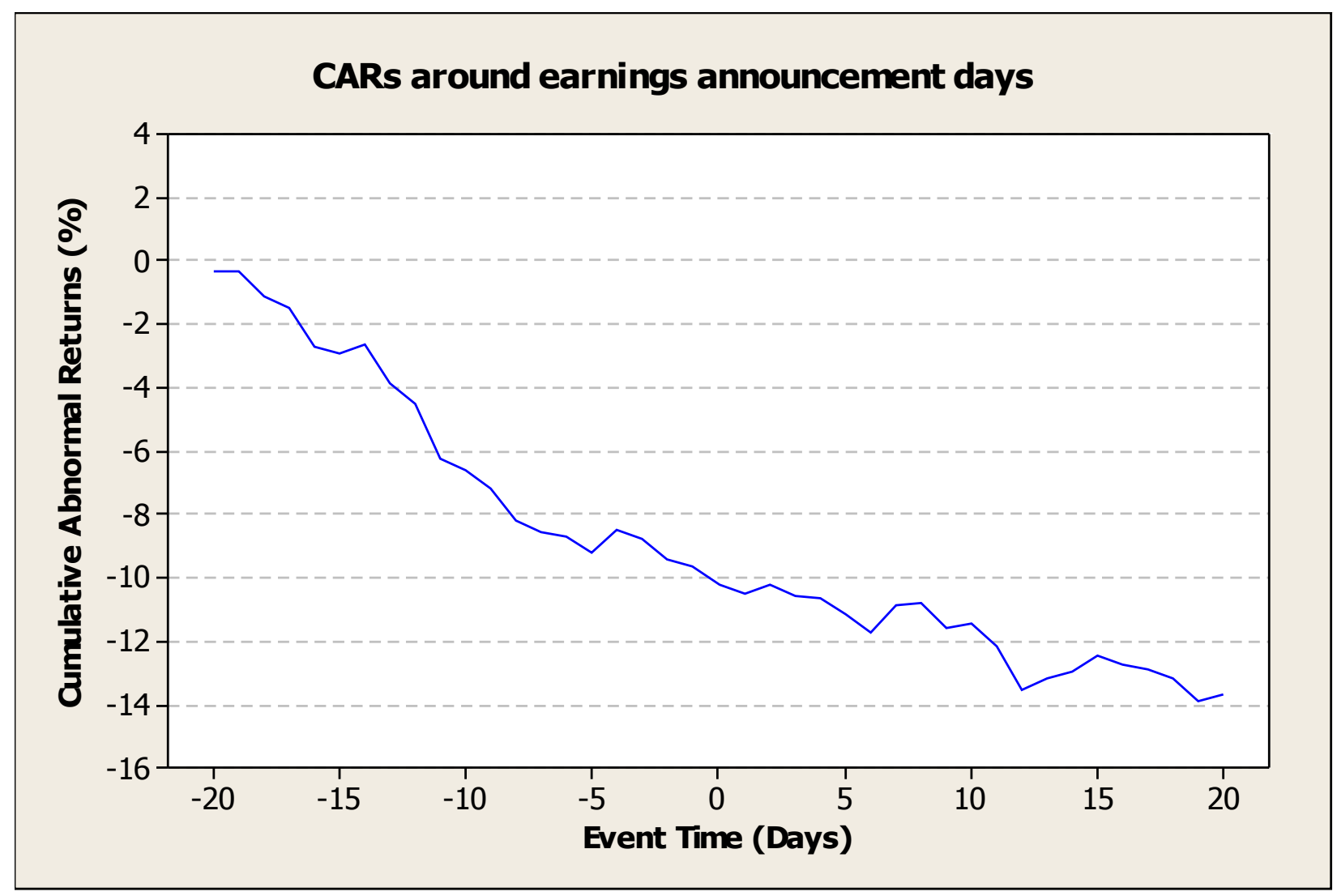

Visual inspection of the plot in Fig.1 reveals that the CARs over the entire event window are all significantly negative. The results clearly show evidence of a significant negative association between cumulative abnormal stock returns and the days surrounding earnings announcements for the sample of firms over the study period.

\section{Discussion of Findings and Implications}

Several interesting points for discussion emerge from the findings of this study. First, a general negative market reaction in the days surrounding the announcement of earnings is contrary to our expectations because our study period, 2005 to 2008, coincides with the period 
when the Nigerian stock market index recorded massive growth and most firms announced positive year-end earnings results.

The results, far from being conclusive, could be a reflection of the low level of investor literacy which is characteristic of a typical African emerging market such as Nigeria. The argument here is that unsophisticated and poorly-informed investors would fail to appreciate the full (and correct) implications of earnings information disclosures by failing to form an unbiased expectation of future earnings immediately upon receipt of current earnings ( $\mathrm{Ng}$ et al., 2008). This may mean that a significant bit of the response does not occur until sometime in the distant future. This explanation is closely related to the 'delayed price response' argument highlighted by Ball and Kothari (1991) who demonstrate that huge transaction and trading costs and poor information dissemination create significant impediments to trading thereby preventing a correct and complete response to earnings announcements. Furthermore, it is typical of firms listed on the NSE to delay the release of their annual earnings result for diverse reasons (Adelegan 2004). According to Chambers and Penman (1984), firms that do not announce earnings early send signals of negative news and thus earn negative pre-announcement and post-announcement abnormal returns. These arguments therefore may provide some explanation for the results we have found in this study.

Second, the results in Table 3 indicate that the greatest magnitude of price reaction takes place in the pre-announcement period. It is imperative to state that given the peculiar nature of the information environment of the Nigerian stock market, the significant abnormal returns recorded in the period prior to the announcement dates could as well be driven by insider dealings and not necessarily the information content of earnings disclosures. As Osei (2002) points out, emerging stock markets in Africa (with the possible exception of South Africa) are 
not known to be efficient due to the numerous institutional, infrastructural and regulatory weaknesses, including poor corporate governance practices, all of which combine to create room for unequal access to information. Also, because laws relating to insider dealings are not known to be enforced, due in part to widespread corruption, the information environment may permit a relatively high incidence of private acquisition of information, and possible manipulation of trade, by officials, managers and other insiders. As a result, significant pre-announcement price reactions to earnings information disclosures may be recorded.

Third, the pattern reported in fig. 1 is consistent with the post earnings announcement drift (PEAD) hypothesis documented in the literature and empirically supported by previous studies in the Africa region by Oludoyi (1999) and Osei (2002). This finding contradicts the semi-strong form of the EMH and instead provides some support for the postulations of the behavioural school. Several explanations may be put forward to explain this result. One, scant information relating to securities in markets may lead to uncertainty in those markets which, in turn, may result to speculative and sentiment-based investment behaviour (Hirota and Sunder, 2002). Two, it is not uncommon for firms in Nigeria, and elsewhere in Africa, not to release their earnings reports voluntarily and in a timely fashion. These scenarios may ultimately lead to 'herding' mentality amongst investors which, in turn, may result in significantly large and persistent price movements around earnings disclosure dates.

On the whole, our findings suggest that patterns exist and stock price reactions to earnings disclosures are not random for the sample of firms in our study. While the results contradict the efficient markets hypothesis, it appears to offer some support for the behavioural model. Furthermore, as most stock markets in Africa share similar institutional and market characteristics (Yartey and Adjasi, 2007), the implications of our findings may prove to be 
potentially relevant to issues concerning the informational efficiency of stock markets domiciled in other developing African countries, and could potentially serve as a basis for similar investigation in other stock markets across the region.

\section{Conclusion and Recommendations}

This paper has examined the nature and extent of stock market responsiveness to companies' annual earnings information releases on the Nigerian stock exchange (NSE). Specifically, the study assessed the information content and usefulness of earnings releases to investors on the NSE, by measuring the speed of reaction of the market to information contained in firms' earnings disclosures. Consistent with evidence documented in the extant literature, we find support for the information content hypothesis. However we fail to find evidence of efficient adjustment of stock prices to information contained in earnings announcements for the sample of firms, as prices continue to drift 20 days after the announcement date. The observation that stock prices drift in the post-announcement period offers some support for behavioural finance theory.

Overall, the results from our study suggests that stock price changes in Nigeria, with respect to earnings announcements, are not random but follow a pattern which makes it possible for negative abnormal returns to be earned by trading around earnings announcement dates. This finding contradicts the efficient markets hypothesis and is consistent with results from previous studies by Olowe (1998), Oludoyi (1999) and Adelegan (2009) which found the Nigerian stock market to be informationally inefficient.

The evidence presented in this study brings to fore a number of interesting issues which indicates that a lot needs to be done, particularly by regulators and policy makers, to address the challenges facing the stock market in Nigeria. 
First, we recommend that the regulatory authorities should intensify efforts to ensure compliance to insider trading laws by market participants. The authorities need to strengthen their capacity to effectively monitor activities in the market, and to effectively deal with offenders. Su (2003) explained that reduction in unequal access to information helps boost investor confidence and also helps improve the competiveness and informational efficiency of emerging stock markets.

Second, companies should be encouraged to ensure timely release of their financial statements. Market regulators and policy makers need to impose penalties on companies that delay the release of their results. According to Chambers and Penman (1984), firms that do not announce earnings early, send negative signals to market participants, and this may result in speculative investment behaviour. Timely release of financial information therefore is expected to help discourage unnecessary speculation by investors while it attracts investors, boosts liquidity and helps improve the informational efficiency of the stock market.

Third, given the preponderance of poorly-informed individuals (and firms) on the Nigerian market, measures should be taken to implement educational programmes in order to increase awareness about stock market activity. Educating the public (individuals and firms) on the workings and benefits of participating in the stock markets is expected to not only attract an increased number of participants, but also boost liquidity (Yartey and Adjasi, 2007).

Also, large institutional and foreign investors should be attracted and encouraged to participate on the Nigerian stock market. The widely held consensus is that institutional and international investors have a greater capacity to conduct extensive security analyses. On the whole it is expected that, by reducing information asymmetry amongst market participants, the activities of institutional investors would help improve availability of relevant financial 
information and the overall quality of the information environment of the Nigerian stock market. It is also expected that this would positively impact on corporate governance practices of domestic firms, protection of the rights of minority shareholders and general market discipline and transparency. La Porta et al, (1999) found evidence of a positive correlation between the quality of shareholder protection and liquidity of stock markets in 49 countries.

Finally, given the relatively small sample size, our results should be interpreted with caution. Future research therefore might be required to analyse a broader sample size in order to provide more comprehensive evidence. Additionally, as this study is limited in scope to a single developing market, future work might require similar analysis to be carried out for other developing markets in the Africa region to ascertain the extent to which the findings from this study are generalisable. Lastly, investigating share price response to interim reports and quarterly earnings announcements offers a potentially interesting avenue for future research in developing markets.

\section{References}

Adelegan, O.J. (2003), "Capital Market Efficiency and the Effects of Dividend Announcement on Share Prices in Nigeria" African Development Review, Vol. 15 Nos. 2\&3 pp: 218-236.

Adelegan, O. J. (2004), "How efficient is the Nigerian Stock Market: Further evidence" African Review of Finance and Banking, pp: 145-165.

Adelegan, O.J. (2009), "Price Reactions to Dividend Announcements on the Nigerian Stock Markets" AERC Research Paper 188, Nairobi: African Economic Research Consortium 
Alford, A., Jones, J., Leftwish, R. and Zmijewski, M. (1993), "The relative informativeness of accounting disclosures in different countries" Journal of Accounting Research Vol.31 pp: 183223

Aloui, C., (2005), "Long-range dependence in daily volatility on Tunisian stock market" Economic Research Forum Working Paper 40, 3-25

Avramov, D., Chordia, T. and Goyal, A. (2006), "Liquidity and autocorrelations in individual stock returns", Journal of Finance, Vol. 61 pp: 2365-2394.

Ball, R.J. and Brown, P. (1968), "An empirical evaluation of accounting income numbers", Journal of Accounting Research Vol. 6 pp: 159-178

Ball, R. and Kothari, S. (1991), "Security Returns Around Earnings Announcements" The Accounting Review Vol. 66 pp: 718-738.

Beaver, H.W (1968), “The Information Content of Annual Earnings Announcements" Journal of Accounting Research, Vol. 6 pp: 67-92

Chambers, A.E. and Penman S.H. (1984), "Timeliness of reporting and the stock price reaction to earnings announcements" Journal of Accounting Research: pp.21-47.

Chordia, T. and Shivakumar, L. (2005), "Earnings and price momentum", Journal of Financial Economics, 80, pp: 627-656

Chordia, T., Goyal, A., Sadka, G., Sadka, R. and Shivakumar, L. (2009), "Liquidity and post earnings announcement drift" Financial Analyst Journal Vol. 65 No. 4 pp: 18-33

Cready, W. M. and Gurun, U. G. (2010), "Aggregate Market Reaction to Earnings Announcements" Journal of Accounting Research Forthcoming: Available at SSRN: http://ssrn.com/abstract=1536894

Ederington, L. H. and Lee, J. H. (1995), “The short-run dynamics of the price adjustment to new information" Journal of Financial and Quantitative Analysis Vol. 30 pp: 117-134 
Elsharkawy, A. and Garrod, N. (1996), “The impact of investor sophistication on price responses to earnings news" Journal of Business Finance \& Accounting Vol. 23 No. 2 pp: $221-236$

Fama, E., Fisher, L., Jensen, M. and Roll, R. (1969), “The Adjustment of Stock Prices to New Information”, International Economic Review Vol. 10 pp: 1-21.

Fama, E. (1970), "Efficient Capital Markets: A Review of Theory and Empirical Work" The Journal of Finance, Vol. 25, No. 2, pp. 383-417

Fifield, S.G.M., Power, D.M., and Sinclair, C .D. (2002), "Macroeconomic Factors and Share Returns: An Analysis Using Emerging Market Data" International Journal of Finance and Economics Vol. 7 pp: 51-62

Firth, M. (1981), “The relative information content of the release of financial results data by firms" Journal of Accounting Research Vol. 19 No. 2 pp: 521-529

Fleming, M., and Remolona, E. (1999), "Price formation and liquidity in the U.S. Treasury market: The response to public information" Journal of Finance Vol. 54 pp: 1901-1927.

Greene, J.T and Watts, S.G (1996), "Price Discovery on the NYSE and the NASDAQ: The Case of Overnight and Daytime News Releases” Financial Management Vol. 25 pp: 19-42

Gutierrez, R. C. and Kelley, E. K. (2006), "Evidence to the contrary: weekly returns have momentum” Working Paper (University of Oregon, 2006).

Harvey, C.R., (1995), "Predictable Risk and Returns in Emerging Markets", Review of Financial Studies, Vol. 8 No. 3 pp: 773-816

Hirota, S., Sunder, S., (2002), “Stock Market as a 'beauty contest': Investor Beliefs and Price Bubbles sans Dividend Anchors". Waseda: Institute of Finance Working Paper 03-004, 1-62. 
Hirshleifer, D. (2001), "Investor Psychology and Asset Pricing" Journal of Finance Vol. 56 pp: $1533-1597$

Kausar, A. and Taffler, R. (2006), "Testing behavioural finance models of market under- and overreaction: Do they really work?" Working Paper (University of Edinburgh, 2006)

La Porta, R., Lopez-de-Silanes, F., and Shleifer, A. (2003), "What Works in Securities Laws?" NBER Working Paper No. 9882, Boston: National Bureau of Economic Research

MacKinlay,A. C. (1997), "Event studies in economics and finance", Journal of Economic Literature, vol. 35, pp: 13-39.

Ng J., Rusticus, T. and Verdi, R. (2008), "Implications of transaction costs for the post-earnings announcement drift" Journal of Accounting Research Vol. 46 No. 3 pp: 661-696.

Okpara C. G. (2010), “Analysis of weak-form efficiency on the Nigerian stock market: Further evidence from GARCH model” International Journal of Applied Economics and Finance Vol. 4 pp: $62-66$.

Olowe, R.A. (1998), "Stock Splits and the Efficiency of the Nigerian Stock Market", African Review of Money, Finance and Banking, Vol.1-2, pp: 97-125.

Oludoyi, S.B. (1999), 'Capital Market Efficiency and the Effects of Earnings Announcements on Share Prices in Nigeria' unpublished PhD thesis, University of Ibadan, Nigeria.

Osei, K. A. (2002), "Asset Pricing and Informational Efficiency of the Ghana Stock Market" AERC Research Paper 115, Nairobi Kenya: African Economic Research Consortium.

Pope, P. and Inyangete, C. G. (1992), "Differential information, the variability of UK stock returns, and earnings announcements" Journal of Business Finance \& Accounting Vol. 19 No. 4 pp: $603-23$. 
Sponholtz, C. (2005), "The information content of earnings announcements in Denmark", EAA Conference, Prague 2005: European Accounting Association Conference

Su, D. (2003), "Stock Price Reactions to Earnings Announcements: Evidence from Chinese Markets", Review of Financial Economics Vol. 12 pp: 271-286

Subrahmanyam, A. (2007), "Behavioural Finance: A Review and Synthesis", European Financial Management, Vol. 14 No. 1 pp: 12-29

Yartey C. and Adjasi, C.K (2007), "Stock Market Development in Sub-Saharan Africa: Critical Issues and Challenges, IMF Working Paper WP/07/209, Washington: International Monetary Fund. 